УДК 811.112.2’255.4:821.113.2](042,2)

DOI https://doi.org/10.26661/2414-9594-2020-2-9

\title{
ОСОБЛИВОСТІ ЗБЕРЕЖЕННЯ НАРАТИВНОЇ МОДЕЛІ «АВТОР-ОПОВІДАЧ-ПЕРСОНАЖ» У ПЕРЕКЛАДІ НІМЕЦЬКОМОВНИХ ТВОРІВ (НА МАТЕРІАЛІ РОМАНУ Г. ГЕССЕ «СТЕПОВИЙ ВОВК»)
}

\author{
Гумений В. В. \\ в. о. викладача кафедри романо-германської філологї̈ та перекладу з німецької мови \\ Чорноморський національний університет імені Петра Могили \\ вул. 68 Десантників, 10, Миколаїв, Україна \\ orcid.org/0000-0003-1270-8893identityisunclear@gmail.com
} Ключові слова: наратор,
реципієнт, інтерпретація,
стилістика, модель.
У статті проведено аналіз лексичних і стилістичних особливостей моделі «автор-оповідач-персонаж» у романі Г. Гессе та його перекладах; встановлено стан охоплення проблематики дослідження наративу у перекладах англійською, українською та російською мовами. Також була аргументована необхідність акцентування уваги на стилістиці нарації автора та її відтворення перекладачами для визначення рівня збереження моделі «автор-оповідач-персонаж».

Мета роботи полягає у висвітленні особливостей перекладу наративних моделей як елемента мовної картини у германістиці на матеріалі дослідження роману «Степовий Вовк», а також розгляді виявлених положень на прикладі перекладу моделі «автор-оповідач-персонаж» i визначення основних ознак ретрансляції стилістики використаних наративних конструкцій автора у перекладах i їхнього впливу на масового читача.

У досліджені текстів автора застосовано методи лексичного та стилістичного аналізу, який виокремлює досліджувану наративну модель, використану для вивчення лінгвістичної складової частини роману Германа Гессе. Метод етимологічного аналізу уможливив виявлення модифікацій наративних моделей у перекладі та вплив мовленнєвого апарату автора на реципієнта (читача). Метод контекстуального аналізу був задіяний для виявлення характерних рис, які відповідають модерністському стилю Германа Гессе, мовних засобів репрезентації його наративу.

Встановлено першочергову домінанту моделі «автор-персонаж» у тексті оригіналу автора та перекладах російською, українською й англійською мовами, котра на семантичному рівні впливає на рівень релевантності нарації центральної події в аналізованому романі. Водночас фактичний виклад нарації диференціюється із нагромадженням рецептивно-інтерпретаційних можливостей, які реалізує читач як посередник цих текстів.

Також встановлено, що наративна модель «оповідач-персонаж» у перекладах роману «Степовий Вовк» матеріалізується крізь мовлення «надійного» наратора, який у текстах перекладу цілковито розчиняється у свідомості головних персонажів. 


\title{
FEATURES OF NARRATIVE MODEL "AUTHOR-NARRATOR-CHARACTER" PRESERVATION IN TRANSLATION OF GERMAN-LANGUAGE WORKS (ON THE MATERIAL OF G. HESSE'S NOVEL "STEPPENWOLF")
}

\author{
Humenyi V. V. \\ Acting Lecturer at the Department of Roman-Germanic Philology and Translation \\ Petro Mohyla Black Sea National University68 Desantnykiv str., 10, Mykolaiv, Ukraine \\ orcid.org/0000-0003-1270-8893 \\ identityisunclear@gmail.com
}

Key words: narrator, recipient, interpretation, stylistics, model.
This article analyzes the lexical and stylistic features of the model "authornarrator-character" in the novel by G. Hesse and his translations; the state of coverage of narrative research in English, Ukrainian and Russian translations has been established. It was also argued the need to focus on the style of the author's narration and its reproduction by translators to determine the level of preservation of the model "author-narrator-character".

The aim of the work is to highlight the peculiarities of the translation of narrative models as an element of the linguistic picture in German studies on the material of the study of the novel "Steppenwolf", as well as consideration of the identified provisions on the example of translation of the model "authornarrator-character" in translations and their impact on the mass reader.

In the research of the author's texts the method of lexical and stylistic analysis is applied, which distinguishes the studied narrative model, which is used in the study of the linguistic component of Hermann Hesse.

The method of etymological analysis made it possible to identify modifications of narrative models in translation and the influence of the author's speech apparatus on the recipient (reader). The method of contextual analysis was used to identify the characteristics that correspond to the modernist style of Herman Hesse, the linguistic means of representation of his narrative).

The primary dominant of the "author-character" model is established in the author's original text and translations into Russian, Ukrainian and English, which at the semantic level affects the level of relevance of the narrative of the central event in the analyzed novel. At the same time, the actual presentation of the narrative is differentiated from the accumulation of receptive-interpretive possibilities, which the reader realizes as a mediator of these texts.

Also in this study was found that the narrative model "narrator-character" in the translations of the novel "Steppenwolf" materializes through the speech of a "reliable" narrator, who in translations is completely dissolved in the minds of the main characters.
Наративні моделі, з погляду лінгвостилістичних досліджень (Дж. Ділі, Ю. Гутерман), відтворюють певні алгоритми, які спонукають до здійснення людиною вчинків, однак у сучасній наратології (В. Телія, О. Падучева, О. Мороховський) ці алгоритми вже не відповідають первісному психоментальному складу особистості, збуджуючи та змінюючи сприйняття читачем послідовності отримання інформації від автора, розповідача й автора, що вимагає подальшого та більш грунтовного дослідження у цій сфері.

Мета роботи полягає у спробі доведення твердження, за яким наративна модель «автор-оповідач-персонаж» $\epsilon$ способом ретрансляції певного повідомлення автора через поєднання логічних i емоційних компонентів стану оповідача та безпосередньо персонажа на лексичному та стилістичному рівнях, що впливає на свідомість реципієнта.

У наративі аналізованого оповідання домінує перша особа однини як граматична форма повістування, притаманна усім типам згаданих вище нараторів твору. Відчутне чітке розмежування між «я-слухачем», або «я-свідком» оповіді, та «я - оповідачем власної трагедії життя». «Я-оповідач» реалізується крізь призму спогадів наратора-свідка / слухача.

Говорячи про використання неологізмів у творі Г. Гессе, насамперед слід відзначити широке 
використання метамовно маркованих оказіоналізмів, прив'язаних саме до тексту роману «Степовий вовк», значення яких намагається розтлумачити сам автор:

Der „Selbstmörder" - und Harry war einer braucht nicht notwendig in einem besonders starken Verhältnis zum Tode zu leben - dies kann man tun, auch ohne Selbstmörder zu sein. [6, c. 66].

У перекладі українською мовою дуже яскраво відчувається та експресія та глибина оказіоналізмів, що є в оригіналі. Тут автор перекладу так само намагається передати експресивність тексту, але, з іншого боку, не завжди графічно позначає ті лексеми, які в оригіналі мають особливе значення:

Самогубеиь - а Гарі був одним із них - не конче перебуває в дуже близьких стосунках зі смертю; до таких стосунків можна дійти і не бувши самогубием [7, с. 66].

Як зауважив Дж. Ділі: «Першою з оповідних універсалій $\epsilon$ власне універсальна роль оповіді [narrative] як основи передавання культури основи суто людського семіозису, за допомогою якого біологічна спадковість переходить у кумулятивне передавання навчання, що уможливлене єдино завдяки оповіді» [1, с. 38-39].

Саме слова іншомовного походження становлять для наративної моделі автора дуже важливий і потужний інструмент створення експресивності й оригінальності побудови речень. Вбачаючи великий стилістичний потенціал у словах іншомовного походження, Г. Гессе використовує їх скрізь у тексті, вкладаючи їх в уста майже усіх героїв:

1. Das mit dem Foxtrott, ich musste die ganze Zeit daran denken [6, c. 140].

2. „Herrlich“, rief ich, ,, und wenn es dir wirklich gelingt, mir das Tanzen beizubringen, dann bekommst du das Grammophon als Honorar. Einverstanden?" [6, c. 141].

3. Da stand nun wieder solch ein Angriff, schlecht geschrieben, halb von Redakteur selbst verfasst, halb aus den vielen ähnlichen Aufsätzen der ihm nahe stehenden Presse zusammengestohlen [6, c. 142].

У перекладі маємо:

1. Та з тим фокстротом, він мені весь час не сходив з думки [8, с. 140].

2. Чудово, - сказав я. - I якщзо ти справді навчиш мене танцювати, я тобі віддам грамофон замість гонорару, згода? [8 с. 149].

3. І ось знов з'явилася така стаття, кепсько написана, - редактор зліпив ї̈ наполовину зі своїх власних фраз, а наполовину з накрадених по газетах такого самого напрямку [8, с. 149].

Деякі дослідники викладу наративних моделей виділяють оцінну (аксіологічну) модальність як першочерговий і потужний інструмент впливу наративної складової частини на читача. «Оцінна модальність, - як зазначає науковець В.Н. Телія, - це зв'язок, що встановлюється між ціннісною орієнтацією мовця / слухача та $<\ldots>$ реалією $<\ldots>$ що оцінюється позитивно чи негативно на якійсь підставі (емоційній, етичній, утилітарній та ін.) відповідно до “стандартів” буття речей чи положення справ у деякій картині світу, яка лежить в основі норм оцінки» [3, с. 22-23].

Дослідниця Ю. Гутерман констатує середній обсяг елементарних речень у німецькій художній літературі в динаміці «від 7-9 речень ХІХ ст. до 15-16 слів у реченні, у Г. Гессе ж середньо речення розбудовуються до 40-50 одиниць. Водночас значно збільшується розмір абзацу» [2, с. 150].

Ця наукова практика була грунтовно доповнена працями мовознавця та текстолога О.В. Падучевої. Вона зазначає, що «якщо наративні моделі, які пов'язують автора й оповідача, з'ясовують принципи функціонування наративу 3 теоретико-літературознавчих позицій, то лінгвістика наративу передбачає виявлення основних тенденцій форматування й ведення оповіді з погляду мовознавства, тобто семантичної та граматичної категорій» [4, с. 321]. «Через неповноцінність комунікативної ситуації сприйняття художнього тексту, де автор відділений від свого висловлювання, читач має справу тільки 3 текстом, а 3 автором - лише настільки, наскільки він відображений у цьому тексті. Прочитане у творі читач сприймає як повідомлене йому оповідачем» [4, с. 200-201].

Проблему «Степового вовка», самотності й ізоляції успішно переборов і сам Гессе, адже «магічний театр» - не найсерйозніший психоаналіз. Глибоке знання психології, захоплення східною філософією, заняття медитацією відкрили Гессе «шлях до смислових глибин», наблизили до розуміння основ світу і життя, допомогли перебороти «вовка» у самому собі.

О. Мороховський вважав, що «смисли тексту мають певну ієрархію, тобто вони взаємопов'язані, взаємозумовлені та взаємно підпорядковані. Це дає змогу визначити зміст тексту як деяку структуру смислів» $[5$, с. 10$]$.

На переконання Т. Гундорової, особливо активним у звільненні читача від тиску авторської інтенції є саме літературний період модернізму, який «руйнує, розбиває, диференціює картину замкненого світу, накладає кілька суб'єктивних перспектив, повертає відчуття свіжості того, що вже стилістично оброблене та створює ілюзію спонтанності того, що стилізується. У такий спосіб він активізує процеси сприйняття, конструює «інакшість» самого читача / глядача. Тобто комунікативна утопія модернізму проектує, трансцедентує читача / глядача поза замкнуті межі буденного і традиційного, відкриваючи перспективу іншого сприйняття, а отже, й іншого буття» $[10$, c. $256-257]$ : 
Hier muß ich eine psychologische Anmerkung einfügen. Obgleich ich über das Leben des Steppenwolfes sehr wenig wei $\beta$, habe ich doch allen Grund, $z u$ vermuten, daß er von liebevollen, aber strengen und sehr frommen Eltern und Lehrern in jenem Sinne erzogen wurde, der das „Brechen des Willens" zur Grundlage der Erziehung macht [6, c. 34].

And here I cannot refrain from a psychological observation. Although I know very little of the Steppenwolf's life, I have all the same good reason to suppose that he was brought up by devoted but severe and very pious parents and teachers in accordance with that doctrine that makes the breaking of the will the corner-stone of education and upbringing. But in this case the attempt to destroy the personality and to break the will did not succeed [7, c. 34].

Тут я должен вставить одно психологическое замечание. Хотя я мало что знаю о жизни Степного волка, у меня есть все причины полагать, что любящие, но строгие и очень благочестивые родители и учителя воспитьвали его в том духе, который кладет в основу воспитания «подавление воли». Так вот, уничтожить личность, подавить волю в данном случае не удалось, ученик был для этого слишком силен и тверд, слишком горд и умен [8, с. 38].

Тут я мушу навести одне своє психологічне спостереження. Хоч я дуже мало знаю про життя Степового Вовка, все ж таки маю всі підстави вважати, що прихильні до нього, але суворі $\check{u}$ дуже побожні батьки і вчителі виховували його на засадах «ламання волі». Але стерти індивідуальність $і$ зламати волю иього учня не вдалося, надто він був сильний і твердий, надто гордий $i$ розумний [9, с. 37].

Як було відзначено Л. Кецба, Г. Гессе використовує прийоми та засоби ритмування оповідання. У романі функційно переосмислюється система внутрішніх повторів, яка в автентичному тексті спочатку мала чисто прагматичний характер - засвоєння і запам'ятовування реципієнтом [11, c. 301].

У роман «Степовий вовк», що виділяється серед гессевських творів своєю «фундаментальністю», введені два повноцінні (24 і 30 малих, композиційно організованих) вірші. Дослідники відзначають їхні невеликі поетичні цінності (зокрема просту побудову, схему «а-в-а-в»), оскільки не розглядають ці вірші як частину цілісної оповідної моделі, що слугує мостом між персонажною оповіддю й авторським стилем, включення поетичних текстів у роман психологічно зумовлене, i розгляд прозометричних особливостей «Степового вовка» доводить це:

Zwei Tage später brachte ein Fuhrmann die Sachen des Fremden, der Harry Haller hieß. Ein sehr schöner Lederkoffer machte mir einen guten Ein- druck, und ein großer flacher Kabinenkoffer schien auf frühere weite Reisen zu deuten, wenigstens war er beklebt mit den vergilbten Firmenzetteln von Hotels und Transportgesellschaften verschiedener, auch überseeischer Länder [6, c. 9]

Two days after this the stranger's luggage - his name was Harry Haller - was brought in by a porter. He had a very fine leather trunk, which made a good impression on me, and a big flat cabin trunk that showed signs of having traveled far - at least it was plastered with labels of hotels and travel agencies of various countries, some overseas [7, c. 9].

Два дня спустя извозчик доставил вещи незнакомиа, которого звали Гарри Галлер. Очень красивый кожаный чемодан произвел на меня хорочее впечатление, а плоский кофр свидетельствовал о прежних дальних поездках, во всяком случае, он был облеплен пожелтевшими ярльками отелей и транспортных агентств разных стран, даже заморских [8, с. 11].

Через два дні візник привіз речі пожильия. Дуже гарна шкіряна валіза справила на мене добре враження, а чималий плаский саквояж начебто свідчив про колишні далекі мандри, в кожному разі, він був обліплений побляклими етикетками готелів і транспортних атентств різних краӥн, серед них і заморських [9, с. 10].

Фрагментарність і рухливість художньої системи «Степового вовка» не призводять до розпаду цілого на дискретні відрізки, оскільки Г. Гессе за своєю суттю - метафізик, котрий вірить у здатність моральним (творчим) зусиллям гармонізувати вселенський хаос. Тому художня і філософська гра ще «чиста», підпорядкована правилам і онтологічна.

Галлер - це книжник, далекий від практичних інтересів. Він ніде не працює, залежується в ліжку, часто постає чи не опівдні та проводить час серед книг. Як і сам Галлер, оповідач теж називає його Степовим вовком, «забрели в міста, в стадну життя, - ніякий інший образ точніше не намалює цю людину, ï боязкої самотності, iї дикості, її тривоги, іiі туги за батьківщиною та іï безрідності». Герой відчуває в собі дві природи - людини та вовка, але, на відміну від інших людей, втихомирив у собі звіра і привчив підкорятися, людина i вовк в ньому не вживалися і тим більше не допомагали один одному, а завжди перебували у смертельній ворожнечі:

Ich begriff, was mir hier anzuschauen vergônnt war, und begriff nun auch erst dieses Lächeln, dieses Strahlen; es war ein Heiliger und Vollendeter, der mir hier für eine Stunde in seinem Glanz mitzuwohnen erlaubte und den ich Stümper hatte unterhalten, ausfragen und zu einer Konversation verführen wollen [6, c. 171].

Я збагнув, щзо мені судилося тут побачити, збагнув июю усмішку, збагнув, чому він весь світився: 
То був взірецьв людини, святий, щчо давщи мені годину побути в своєму сяйві, а я, недолугий, хотів его залучити до розмови, ставив йому нікчемні запитання [7, с. 180].

Тут ми бачим досягання майже повної імпресивної еквівалентності на формальному рівні, оскільки перекладачі повністю відтворили синтаксичний лад і зберегли емоційну наповненість речення.

Розпочинає текст відсутній наратор, тобто максимально прихований, який представляє ситуації та події 3 мінімальним наративним посередництвом.

Причиною появи у тексті ненадійного наратора $€$ те, що письменник прагнув розкрити власні погляди на події, які трапилися. Г. Гессе тяжіє до варіації сюжету та розвитку подій, він вводить наративну маску задля зосередження уваги читача на нараторі, котрий виступає дійовою особою, тим самим знімаючи відповідальність із автора за достовірність описуваних подій:

Diese Aufzeichnungen - einerlei, wie viel oder wenig realen Lebens ihnen zugrunde liegen mag sind ein Versuch, die große Zeitkrankheit nicht durch Umgehen und Beschönigen zu überwinden, sondern durch den Versuch, die Krankheit selber zum Gegenstand der Darstellung zu machen. Sie bedeuten, ganz wörtlich, einen Gang durch die Hölle, einen bald angstvollen, bald mutigen Gang durch das Chaos einer verfinsterten Seelenwelt, gegangen mit dem Willen, die Hölle zu durchqueren, dem Chaos die Stirn zu bieten, das Böse bis zu Ende zu erleiden. Ein Wort Hallers hat mir den Schlüssel zu diesem Verständnis gegeben [6, c. 89].

These records, however much or however little of real life may lie at the back of them, are not an attempt to disguise or to palliate this widespread sickness of our times. They are an attempt to present the sickness itself in its actual manifestation. They mean, literally, a journey through hell, a sometimes fearful, sometimes courageous journey through the chaos of a world whose souls dwell in darkness, a journey undertaken with the determination to go through hell from one end to the other, to give battle to chaos, and to suffer torture to the full. A remark of Haller's gave me the key to this interpretation [7, c. 92].
Ці записки, байдуже, більше чи менше реальних подій покладено в їхню основу, - спроба подолати широко розповсюджену хворобу часу не замовчуванням чи виправданням ї̈, а перетворенням самої ичієї хвороби в об’єкт зображення. Це справжнісінька мандрівка крізь пекло, часом боязка, а часом мужня подорож крізь хаос затьмареного душевного світу, подорож, почата з твердим наміром переитти пекло, підставити чоло хаосові й вистраждати все до кіния [8, с. 91].

Нижеследуюшиезаписи-неважно, вкакоймере основаны они на реальных событиях, - попьтка преодолеть большую болезнь эпохи не обходным маневром, не приукрашиванием, а попьткой сделать самую эту болезнь объектом изображения. Они представляют собой, в полном смысле слова, сошествие в хаос помраченной души, предпринятое с твердым намерением пройти через ад, померяться силами с хаосом, выстрадать все до конца. Ключ к пониманию этого дало мне одно замечание Галлера $[9$, с. 90].

Отже, наративна модель «автор-оповідач-персонаж» у романі Г. Гессе «Степовий Вовк» є особливим прийомом текстотворення, який виступає обличчям наратора у художньому творі, манерою його повістування, що зумовлюється конкретною ситуацією та мовленнєвою поведінкою різних оповідачів у взаємодії з ідеальним читачем. Це більшою мірою адекватно збережено у перекладах російською, українською й англійською мовами у суб-моделі «автор-персонаж» та «автор-оповідач».

Під час спроби ретрансляції повноцінної наративної моделі «автор-оповідач-персонаж» безпосередність «спілкування» автора 3 читачем у перекладах частково виключає можливість попереднього обдумування, і тому мовлення характеризується граматичними відхиленнями від норми, пропусками, повторами, асоціативним додаванням нових фактів і думок.

Автори перекладів концентрують увагу читача переважно на зорових і слухових образах, за домінантної позиції яких «домальовуються» інші відсутні елементи зображуваної картини чи події, 3 чого можна зробити висновок, що у мовних описах не потрібно наводити експліцитно всі деталі для сприйняття зв'язної моделі реципієнтом.

\section{ЛІТЕРАТУРА}

1. Ділі Дж. Основи семіотики. Львів : Арсенал, 2000. С. 39.

2. Гутерман Ю.О. Поэтика романа Г. Гессе «Игра в бисер» в контексте философии буддизма и даосизма : дис. ... канд. филол. наук : 10.01.05. Моск. пед. гос. ун-т. Москва, 1999. 181 с.

3. Телия В.Н. Типы языковых значений. Связанное значение слова в языке. Москва, 1981. 302 с.

4. Падучева Е.В. Семантические исследования (Семантика времени и вида в русском языке. Семантика нарратива). Москва : Школа «Языки русской культуры», 1996. 464 с.

5. Мороховський О.М. Із неопублікованого. Вісник Київського лінгвістичного ун-ту. Сер. Філологія. 2001. T. 4. № 1. C. 3-19.

6. H. Hesse. Der Steppenwolf. 1927. S. 277 Roman. Berlin : S. Fischer Verlag, 1927. 246 p. 
7. Hesse. H. Steppenwolf: A Novel / Translated by Basil Creighton. 2002. 224 p.

8. Гессе. Г. Степовий вовк / пер. С.О. Попович) : Роман. Харків : Видавничий центр «Фоліо», 2012. $252 \mathrm{c}$.

9. Гессе. Г. Степной волк / пер. С.К. Апт) : Роман. Москва : Издательство «АСТ», 2011. 256 с.

10. Гундорова Т. Проявлення слова. Дискурсія раннього українського модернізму. Постмодерна інтерпретація. Львів : Літопис, 1997. С. 290.

11. Кецба Д.Н. Феномен гри у романах Г. Гессе. Одеса, 2007. 316 с.

\section{REFERENCES}

1. Dili D. (2000) Osnovi semiotiky [Fundamentals of semiotics]. Lviv : Arsenal. P. 39.

2. Guterman Yu.O. (1999) Poetika romana G.Gesse "Igra v biser" v kontekste filosofii buddizma i daosizma [Poetics of Hesse's novel "The Glass Bead Game" in the context of the philosophy of Buddhism and Taoism] Dis. Cand. philol. Sciences: 10.01.05 / Mosk. ped. gos. un-t. 181 p.

3. Teliya V.N. (1981) Tipy yazykovyh znachenij. [Types of linguistic meanings Associated meaning of a word in a language]. $302 \mathrm{p}$.

4. Paducheva E.V. (1996) Semanticheskie issledovaniya. (Semantika vremeni i vida v russkom yazyke. Semantika narrativa) Semantic research. [Semantics of time and type in Russian. Semantics of narrative]. Moskva: Languages of Russian culture. $464 \mathrm{p}$.

5. Morohovskij O.M. (2001) Iz neopublikovanogo [From the unpublished]. Bulletin of the Kiev Linguistic University. Ser. Philology. T. 4. № 1. P. 3-19.

6. Hesse. H. (1927) Der Steppenwolf. Roman. Berlin : S. Fischer Verlag. 246 p.

7. Hesse. H. (2002) Steppenwolf (Translated by Basil Creighton): Novel. 224 p.

8. Hesse. H. (2012) Stepovij vovk. [Steppenwolf] (translated by Y.O. Popovych). Kharkiv : Folio Publishing Center. $252 \mathrm{p}$.

9. Hesse. H. (2011) Stepnoj volk. [Steppenwolf] (translated by S.K. Apt. Moscow : AST Publishing House. $256 \mathrm{p}$.

10. Gundorova T. (1997) Proyavlennya slova. Diskursiya rannogo ukrayinskogo modernizmu. Postmoderna interpretaciya [Manifestation of the word. Discourse of early Ukrainian modernism. Postmodern interpretation]. Lviv : Litopys, P. 290.

11. Kecba D.N. (2007) Fenomen gri u romanah G. Gesse. [The Phenomenon of Game in G. Hesse's Novels]. Odessa : Publishing House "Mova", 316 p. 